\title{
Analysis of Buttering Method on Mechanical Properties Welded Material Low Carbon Steel
}

\author{
Gathot Dwi Winarto ${ }^{1}$, Rivai Wardhani ${ }^{1}$, and Irsyadus Syarif ${ }^{1}$
}

\begin{abstract}
In manufacturing, especially offshore, welding is one of the joining processes (steel) with very tight specification. Preparation time (fitting) both steel material which will be connected, especially when the material cutting process does not allow for mistakes, so when they do tuning of both material be spliced happen distance (gap) in excess of the standard, then the buttering method that does not eat a lot of time, wasted materials and dimensions of objects so it still makes tolerance in otherwise require. Buttering is the adding process of material in welding. It is applied on one or both sides to be connected, with the aim of giving the distance (gap) between the two materials will be in connection with welding processes meet the requirements of the standard (ASME Sec IX, 2010)1. This study aimed to indicate the effect of the buttering in welding. And the variety of wide buttering is $10 \mathrm{~mm}, 15 \mathrm{~mm}$, and $20 \mathrm{~mm}$. Material will be joined with welding process Shield Metal Arc Welding (SMAW). In the test, material is low carbon steel type SA 36. Tests performed were tensile test, impact test, and the test macro etching. By those tests, will be Investigated what the differences between welding without buttering and with buttering. And the final results showed the addition of wide buttering decreased tensile strength, which declines in linear: buttering width $10 \mathrm{~mm}=$ 413.47 MPa, buttering width $15 \mathrm{~mm}=397.48 \mathrm{MPa}$, buttering width $20 \mathrm{~mm}=390.07 \mathrm{MPa}$. In impact strength, it increased, which increasing linear: width $10 \mathrm{~mm}=1.82 \mathrm{~J} / \mathrm{mm}^{2}, 15 \mathrm{~mm}$ width buttering $=1.90 \mathrm{~J} / \mathrm{mm}^{2}, 20 \mathrm{~mm}$ width buttering $=1.94 \mathrm{~J} / \mathrm{mm}^{2}$. And in macro test, it was shown that a Heat Affected Zone (HAZ) in buttering spread larger than HAZ in material without buttering.
\end{abstract}

Keywords-Buttering, SA 36, tensile, impact, macro etch, HAZ.

\section{INTRODUCTION}

$\mathrm{D}$ uring manufacturing process, especially fabrication and erection, welding takes the most important step. In general, there are some welding process types, and one of them is SMAW (Shield Metal Arc Welding). SMAW welding process, generally known as electric welding, is a welding process that using heat to melt the base material and electrode. Heat generated by the electric ion jumps between the cathode and the anode (electrode tip and the surface of the plate to be welded). Generated heat as the result from electrical ions leap can reach $4000^{\circ}$ to $4500^{\circ}$ Celsius in temperature. Voltage source used in SMAW, are two kinds, AC (alternating current) and DC power (direct current). Welding is applied for connecting multi sections into a structure. In process, it must be included the preparation of material, such as bevel, distance area to be welded, and connection forms. One of the stages that have common errors is the cutting process. And if there are errors during cutting step, It will result in the distance, will increase the gap between two parts, further the welding cannot be done directly without special treatment.

Generally, if the gap between two parts too wide, The common way to solve the problem, usually apply buttering on the welded area. By this method, the gap will be reduced significantly. And actually, addition that are applied must be met with several requirements that exist in the code or the standard. But in field, this thing is rarely considered in more detail, and even ignored and not be tested on the buttering areas.

In ASME section IX, it clearly defined that buttering is the addition of material, by welding, on one or both faces

${ }^{1}$ Gathot Dwi Winarto, Rivai Wardhani, and Irsyadus Syarif are with Departement of Mechanical Engineering, Faculty of Industrial Engineering, Institut Teknologi Sepuluh November, Surabaya, 60111, Indonesia. E-mail: gathot.d3mits.its@hotmail.com. of a joint, prior to the preparation of the joint for final welding, for the purpose of providing a suitable transition weld deposit for the subsequent completion of the joint.

Based on those reasons, it is necessary to do research to determine the effect of the buttering width on the mechanical properties, in particular material of low carbon steel.

\section{A. Carbon Steel}

Carbon steel is a metal alloy, combination between iron and carbon with other alloys, such as $\mathrm{Si}$ (silicon), Mn (manganese), $\mathrm{P}$ (Phosphorus), $\mathrm{S}$ (sulfur), and $\mathrm{Cu}$ (copper). A property of carbon steel depends on the carbon content. Therefore the steel can be classified into 3 groups such as low carbon steel with a carbon composition less than $0.30 \%$, medium carbon steel with $0.30 \%-0.45 \%$ carbon, and high carbon steel with carbon content from $0.45 \%$ up to $1.70 \%$.

In this research, used material is classified as ASTM A36, with 400-550 MPa tensile, Yield: $\min 250 \mathrm{MPa}$, elongation: min $20 \%$ as required by ASME section II-A. This material is commonly used for the structure, with carbon content of SA $360.25 \%-0.29 \%$.

\section{B. Buttering}

Buttering having been applied to solve the welding problem, in particular to weld dissimilar materials, the condition that these materials have different melting points, or the other condition because two materials have different weldability (weldability properties), for example, material A with low weldability, will be connected to material B that has better weldability. On the other hand, it could also reduce the gap between two parts, which was usually applied during the erection, due to error at material preparation or error at cutting process. 
Buttering method can be applied not only on one side of the parent metal that will be connected, but also on both sides of the base metal to be welded. These procedures can be applied as listed on the ASME section IX. In this section, it requires the maximal thickness of additional material equals to the thickness of buttering material. If the material is $10 \mathrm{~mm}$ in thickness, so the thickness of material addition is $10 \mathrm{~mm}$ maximum. But in practices, the client has an own specification, by allowing the buttering up to $15 \mathrm{~mm}$ for material thickness $8 \mathrm{~mm}$ on welding dissimilar materials.

\section{SMAW Welding}

Welding process SMAW (Shielded Metal Arc Welding), generally known as electric welding, is a process that uses heat to melt the base material and electrode. The heat generated by the electric ion jumps between the cathode and the anode (electrode tip and the surface of the plate to be welded) . Heat arising from electrical ions leap of this magnitude can be reached 4000 o to 4500 o Celsius . Voltage source is used there are two kinds of AC ( alternating current ) and DC power (direct current).

Because the tip electrode contact the base material, the process of welding ignites, causing a short circuit between them. At the time of short circuit occurs, welder should pull (keep distance between electrode and material base) the electrode to form an electric arc that leaps ions that cause heat. Generated heat will melt the electrode and the base material, due to their melting point temperature, so the liquid electrodes and a liquid base material will be joined together to form the weld metal. To produce a good welded metal and constant arc, welders must keep distance between the tip electrode and the surface of the base material. The best distance from tip electrode to material is as same as the diameter of the electrode is used, as shown in Figure 1 as follows.

Amount of heat / temperature $(\mathrm{H})$ which can melt material is a product of the voltage (E) multiplied by current (I) and time (t), which is expressed in units of joules of heat such as the following formula:

$\mathrm{H}=\mathrm{E} \times \mathrm{I} \times \mathrm{t}$

which:

$\mathrm{H}=$ Heat (joule)

$\mathrm{E}=$ Voltage $($ volt $)$

$\mathrm{I}=$ Currect (ampere)

$\mathrm{t}=$ Time $(\mathrm{sec})$

Straight polarity is more widely used because it has a deep penetration.

\section{Tensile Test}

Tensile strengtt, one of mechanical properties, is very important in a construction design and manufacturing process. Tensile strength of a material was obtained from the tensile test (tension test) which was carried out by standard tests such as ASTM (Assotiation Test and Materials Society) and JIS (Japan Industrial Standard).

In tensile test, during specimen withdrawn, time is being recorded with a chart available on the tensile machine. Plot of stress-strain curve will be generated in the tensile test machine. Data obtained from the tensile machine is usually represented by the applied loadelongation chart (graph $\mathrm{P}-\Delta \mathrm{L}$ ).
1) Tensile strength

Tensile strength (tension strength) states the ability to receive a load of material without causing damage or broken, which is expressed in the maximum stress before failure. It is stated in equation 2 ,

$U_{T S}=\sigma_{U}=\frac{F_{\max }}{A_{0}}$

\section{2) Ductility}

Ductility represents the ability of the material to deform plastically without causing fractures stated percentage of change of length (elongation) Elongation:

$\varepsilon=\left\{\frac{\left(L_{1}-L_{0}\right)}{L_{0}}\right\} \times 100 \%$

$\mathrm{L}_{0}=$ Original gauge length

$\mathrm{L}_{1}=$ Final gauge length at break

$\varepsilon=$ Strain

And ductility also can be expressed by the percentage reduction in cross-sectional area which presentated as the reduction of area.

$R_{A}=\left\{\frac{\left(A_{1}-A_{0}\right)}{A_{0}}\right\} \times 100 \%$

which :

$\mathrm{A}_{1}=$ Final cross sectional area

$\mathrm{A}_{0}=$ Initial cross sectional area

\section{E. Impact Test}

To explore the effects caused by notch, notch shape, temperature and other factors, The impact test is delivered. Impact test can be interpreted as a standardized test that measures the ability of a material to accept the burden of mashed as measured by the amount of energy required to break the specimen with a swing.

The amount of impact energy (Joules) can be viewed on a scale testbed machine. While besarya impact energy can be calculated by the following equation:

$$
\begin{aligned}
& \mathrm{E}_{\mathrm{o}}=\mathrm{W} \cdot \mathrm{h}_{\mathrm{o}} \\
& \mathrm{E}_{1}=\mathrm{W} \cdot \mathrm{h}_{1} \\
& \Delta \mathrm{E}=\mathrm{E}_{\mathrm{o}}-\mathrm{E}_{1}=\mathrm{W}\left(\mathrm{h}_{\mathrm{o}}-\mathrm{h}_{1}\right) \\
& \mathrm{h}_{\mathrm{o}}=\ell-\ell \cos =\ell(1-\cos \alpha) \\
& \mathrm{h}_{1}=\ell-\ell \cos \beta=\ell(1-\cos \beta)
\end{aligned}
$$

substitution eq. 8 and eq. 9 to eq. 7 , then:

$\Delta \mathrm{E}=\mathrm{W} \ell(\cos \beta-\cos \alpha)$

which:

$$
\begin{aligned}
& E_{o}=\operatorname{Initial~Energi~}(J) \\
& E_{1}=\text { Final Energi }(J) \\
& W=\text { Mass of pendulum }(N) \\
& h_{0}=\text { Initial height of pendulum }(m) \\
& h_{1}=\text { Height of pendulum after released }(m) \\
& \ell=\text { Length of pendulum string }(m)
\end{aligned}
$$


$\alpha=$ Initial angle $\left(^{\circ}\right)$

$\beta=$ Final angle $\left({ }^{\circ}\right)$

To know the impact strength impact strength (Is) the impact energy that should be shared with the effective specimen cross-sectional area (A) so that:

$\mathrm{I}_{\mathrm{s}}=\Delta \mathrm{E} / \mathrm{A}=\mathrm{W} \ell(\cos \beta-\cos \alpha) / \mathrm{A}$

\section{F. Macro Etch Testing}

Macro-etching is a method to find a picture of the rough metal or weld metal. The principle works the same as test metallography, only with a microscope only observation process that differentiates. At the macroetching, after etching the specimen in subsequent spray cleaner. While the objects in metallography after etching, we then observed with a microscope as shown in Figure 3.

Size of the main weld metal can be determined by macro-etching test this. For example, the length of the legs of the weld, the weld metal height, and also the amount of dilution of the welding results. Dilution is the amount of weld metal are joined together with metalparent, and its place in the fusion line (base metalweld metal) in percent, which stated in eq.12,

$$
D=\frac{A}{A+B} \times 100 \%
$$

\section{METHOD}

\section{A. Flow chart}

Steps in the research described in the following flow chart (Figure 4).

\section{B. Buttering Weld}

Determination for buttering use in this study refers to the ASME. And in this study using buttering width 10 $\mathrm{mm}, 15 \mathrm{~mm}, 20 \mathrm{~mm}$. Figure 5 shows the scenario buttering

Welding parameters as follows:

$\begin{array}{ll}\text { Material } & \text { : Plat SA 36 } \\ \text { Dimension } & : 300 \times 150 \times 12 \mathrm{~mm} \\ \text { Form } & : \text { Single V-Groove } \\ \text { Type } & : \text { SMAW (DCSP) } \\ \text { Wire } & : \text { E 7016 }(\varnothing 3,2 \mathrm{~mm}) \\ \text { Current } & : 90-100(\mathrm{~A}) \\ \text { Voltage } & : 20-24(\mathrm{~V}) \\ \text { Velocity } & : 1.5-2.2(\mathrm{~mm} / \mathrm{sec})\end{array}$

The addition of buttering have been done after $30^{\circ}$ bevel made, with the addition of $10 \mathrm{~mm}, 15 \mathrm{~mm}$ and 20 $\mathrm{mm}$. Furthermore welding proceed. The next step is leveling with a $30^{\circ}$ bevel grinding, the temperature used during welding at interpass should be kept not less than $60^{\circ} \mathrm{C}$, then continue to the next layer. Welding tempo each layer must be kept.

In this research, welding applied with buttering $10 \mathrm{~mm}$, there was 9 layers. And buttering with $15 \mathrm{~mm}$, welding deposit reached 15 layers. For the last buttering $20 \mathrm{~mm}$, welding deposit was as much as 19 layers.

Joining

After buttering welding was completed, then joining performed, butt joint with SA 36 without buttering material. Figure 6 shows the deposit of weld metal with buttering. And in Figure 7 shows the deposit of weld metal without buttering.
Welding parameters as follows:

$\begin{array}{ll}\text { Material } & \text { : Plat SA 36 } \\ \text { Dimension } & : \text { 300 x 150x 12mm } \\ \text { Form } & \text { : Single V-Groove } \\ \text { Welding machine : SMAW (DCSP) } \\ \text { Welding wire } & : \text { E 7016 (Ø 2,6 \& 3,2 mm) } \\ \text { Current } & : 70-100(\mathrm{~A}) \\ \text { Voltage } & : 18-24(\mathrm{~V}) \\ \text { Velocity } & : 0,9-1.5(\mathrm{~mm} / \mathrm{sec})\end{array}$

\section{RESULT AND DISCUSSION}

\section{A. Tension Test Result}

After tensile test has been done, table 1 show the results. It stated about failure stress $\left(\sigma_{\text {fail }}\right)$, ultimate $\operatorname{stress}\left(\sigma_{\text {ultmate }}\right)$, reduction of area $(\Phi)$, elastic moduli $(E)$ which shown in table 1.

By resuming the resultsof tensile test, it shows in fugure 8, tensile strength of each specimen. And figure 9, it shows trending result of elongation each specimens.

\section{B. Macro Etsa Result}

This test is a way to see the fusion of the weld metal and width of HAZ (Heat-affected Zone) the welding results. Before the macro test, material should be polished, to get the flat surface and shiny by using rubbing paper. Then macro etch was being done, with an etching solution composition, nital $2 \%$, which composed $2 \%$ nitric acid and $98 \%$ alcohol. After observation and measurement of macro photograph etch results showed in Table 2.

\section{Impact Test Result}

Impact test done with $\mathrm{V}$ shape notch in the base metal, weld metal, HAZ (Heat-affected Zone) and buttering. The results of impact test is showed in table 3. While the trend of the impact test results can be seen in Figure 11.

\section{CONCLUSION}

The test results showed the addition of buttering widening decreased tensile strength, which declines in a row as follows: buttering width $10 \mathrm{~mm}=413.47 \mathrm{MPa}$, buttering width $15 \mathrm{~mm}=397.48 \mathrm{MPa}$, buttering width $20 \mathrm{~mm}=390.07 \mathrm{MPa}$. And for impact energy, by applied impact test, buttering width increased impact energy. The increase in a row as follows: buttering width $10 \mathrm{~mm}=147.0$ Joules, buttering width $15 \mathrm{~mm}=149.2$ Joules, buttering width $20 \mathrm{~mm}=149.9$ Joules. And based on the macro etch test, Heat Affected Zone (HAZ) area of weld metal with buttering was greater than area of weld metal without buttering.

\section{REFERENCES}

[1] Fohkard, Erich, (1988). Welding Metallurgy of Stainless Steel, Springer verlag Wien, New York.

[2] ASM Handbook Vol. 1, 8th edition. (2005). Properties and Selection Irons, Steels dan High-Performance Alloys.

[3] ASME Boiler \& Pressure Vessel Code Section IX. (2007). Welding and Brazing Qualification. New York.

[4] Callister, William D Jr. (2007). An Introduction Material Science and Engineering, 7th edition. 


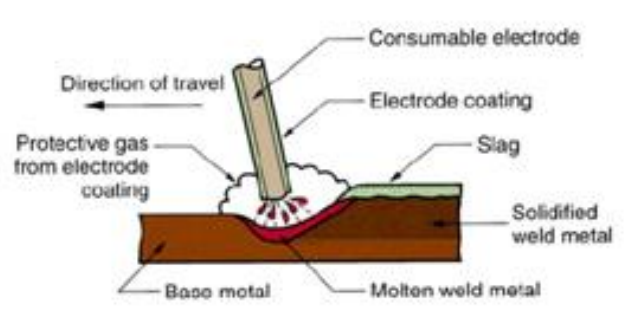

Figure 1. SMAW welding process [1]

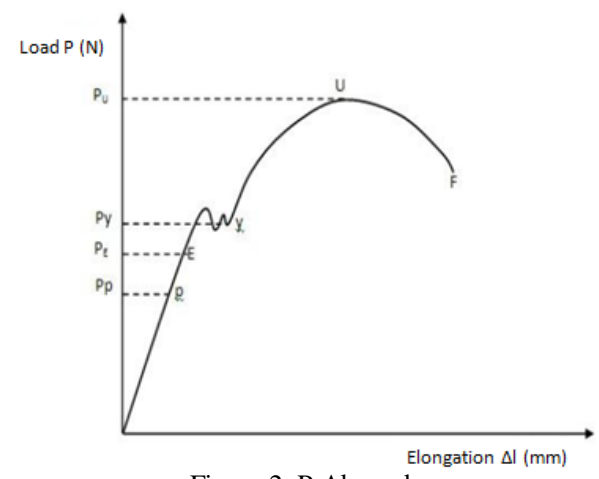

Figure 2. P- $\Delta \mathrm{l}$ graph

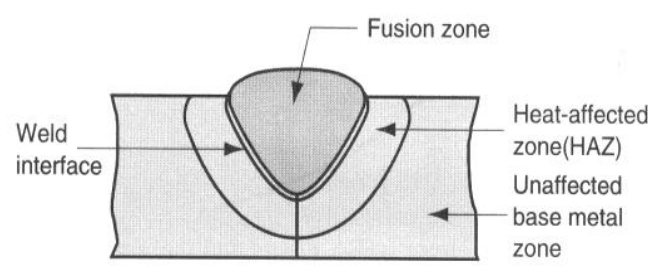

Figure 3. Weld Joint [1]

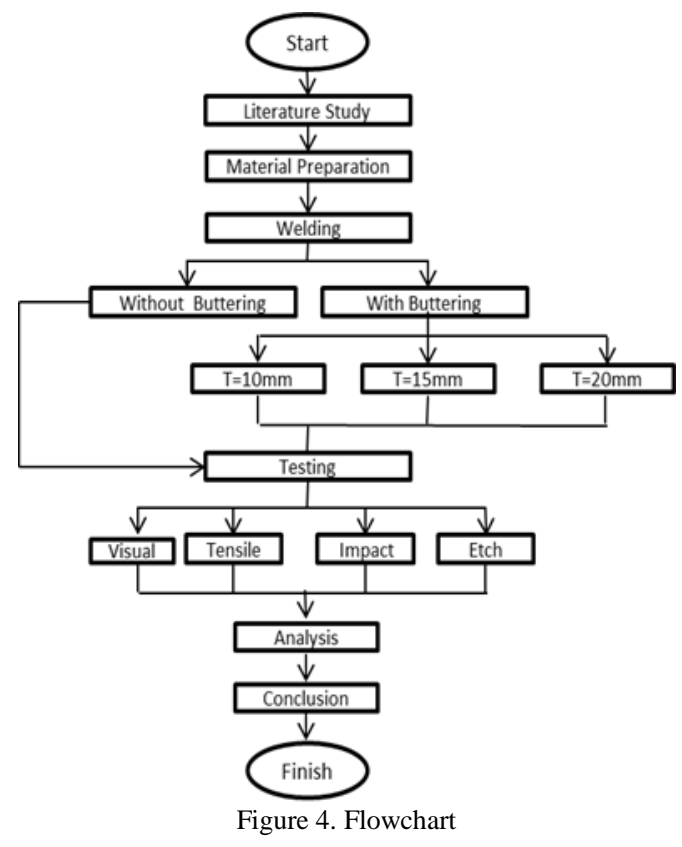

Buttering Sequence

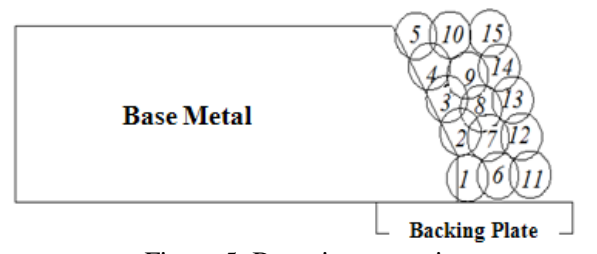

Figure 5. Buttering scenario

Which : (1)First Layer; (2)Second Layer; (3)Third Layer, and so on

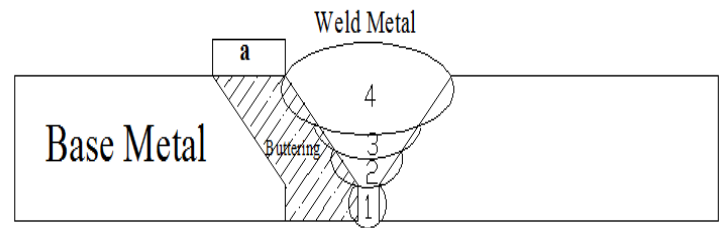

Figure 6. Welding deposit sequence for butt joint

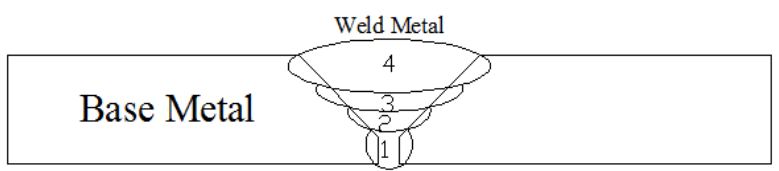

Figure 7. Welding deposit without buttering

Tensile Strength

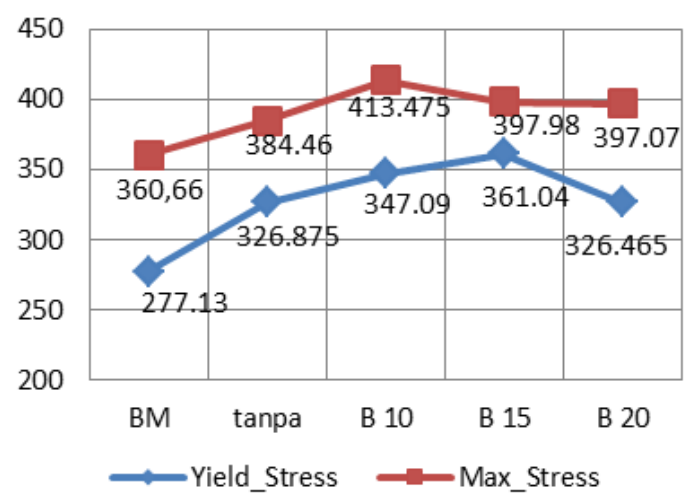

Figure 8 . Trending of tensile strength in tensile test

Elongation [\%]

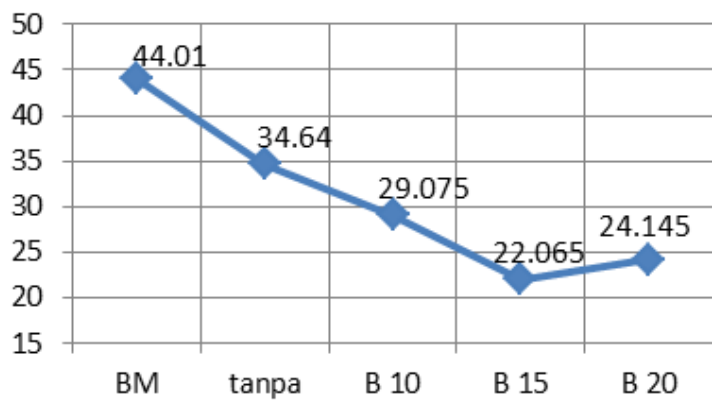

Figure 9. Trending of elongation in tensile test
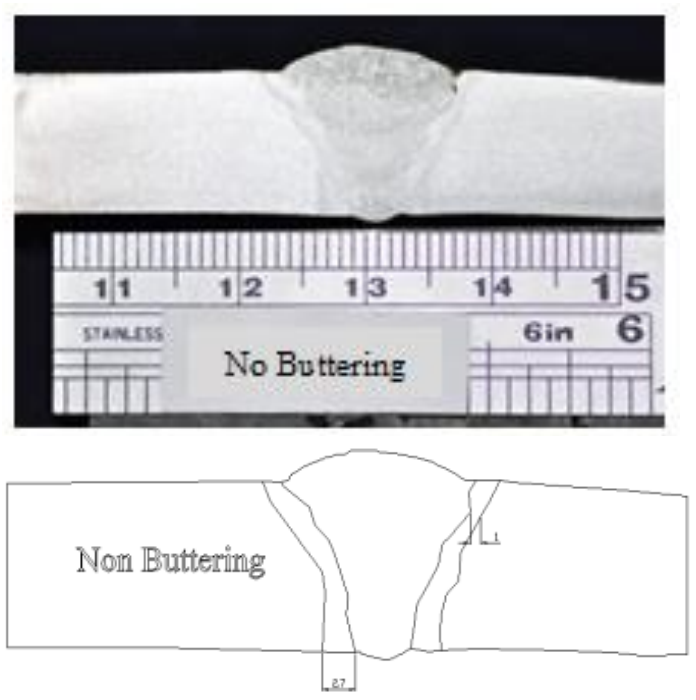

Figure 10. Macro etch photograph result 


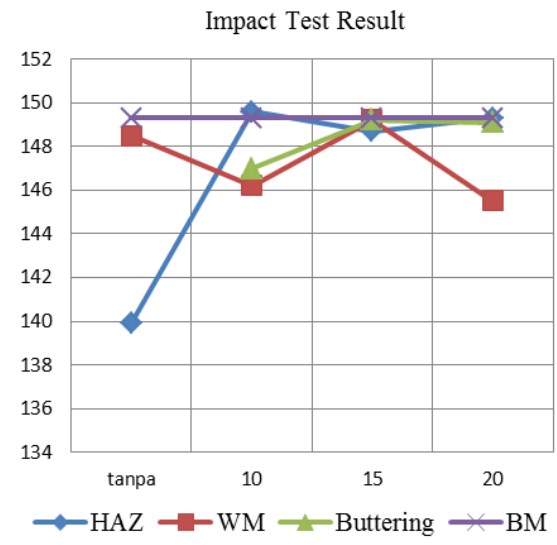

Figure 11. Trending of impact test result

TABLE 1.

REsult OF TENSILE TEST

\begin{tabular}{cccc}
\multicolumn{4}{c}{ RESULT OF TENSILE TEST } \\
\hline \hline Specimen & $\begin{array}{c}\text { Yield Stress } \\
{[\mathrm{Mpa}]}\end{array}$ & $\begin{array}{c}\text { Max Stress } \\
{[\mathrm{MPa}]}\end{array}$ & Elongation \\
\hline BM & 277.13 & 360.66 & 44.01 \\
No & 326.875 & 384.46 & 34.64 \\
Buttering & & & \\
$\quad[\mathrm{NB}]$ & 361.04 & 413.47 & 29.075 \\
$\begin{array}{c}\text { Buttering } \\
10 \mathrm{~mm}\end{array}$ & 347.09 & 397.98 & 24.145 \\
Buttering \\
$\begin{array}{c}15 \mathrm{~mm} \\
\text { Buttering } \\
20 \mathrm{~mm}\end{array}$ & 326.465 & 390.07 & 22.065 \\
\hline \hline
\end{tabular}

TABLE 2.

MACRO ETCH RESULT

\begin{tabular}{cccc}
\hline \hline Name & Defect & $\begin{array}{c}\text { Width of HAZ } \\
{[\mathrm{mm}]}\end{array}$ & $\begin{array}{c}\text { Area of } \\
\text { HAZ }\left[\mathrm{mm}^{2}\right]\end{array}$ \\
\hline $\begin{array}{c}\text { No } \\
\text { Buttering } \\
\text { B } 10\end{array}$ & UC & 1,85 & 49.41 \\
B 15 & NO & 2.50 & 50.60 \\
B 20 & P & 2,75 & 61.00 \\
\hline \hline
\end{tabular}

TABEL 3

\begin{tabular}{|c|c|c|c|}
\hline Specimen & Notch & $\begin{array}{c}\text { Notch } \\
\text { Location }\end{array}$ & $\begin{array}{l}\begin{array}{l}\text { E impact } \\
\text { (Joules) }\end{array} \\
\end{array}$ \\
\hline $\begin{array}{l}\text { SA } 36 \\
\text { No }\end{array}$ & V & $\mathrm{BM}$ & 139.3 \\
\hline $\begin{array}{l}\text { Buttering } \\
\text { Buttering }\end{array}$ & V & HAZ & 149.9 \\
\hline $\begin{array}{c}10 \mathrm{~mm} \\
\text { Buttering }\end{array}$ & V & HAZ & 149.6 \\
\hline $\begin{array}{c}15 \mathrm{~mm} \\
\text { Buttering }\end{array}$ & V & HAZ & 148.7 \\
\hline $\begin{array}{c}20 \mathrm{~mm} \\
\mathrm{No}\end{array}$ & V & HAZ & 147.3 \\
\hline $\begin{array}{l}\text { Buttering } \\
\text { Buttering }\end{array}$ & V & WM & 148.5 \\
\hline $\begin{array}{c}10 \mathrm{~mm} \\
\text { Buttering }\end{array}$ & V & WM & 146.2 \\
\hline $\begin{array}{c}15 \mathrm{~mm} \\
\text { Buttering }\end{array}$ & V & WM & 149.2 \\
\hline $\begin{array}{c}20 \mathrm{~mm} \\
\text { Buttering }\end{array}$ & V & WM & 145.5 \\
\hline $\begin{array}{c}10 \mathrm{~mm} \\
\text { Buttering }\end{array}$ & V & Buttering & 147.0 \\
\hline $\begin{array}{c}15 \mathrm{~mm} \\
\text { Buttering }\end{array}$ & V & Buttering & 149.2 \\
\hline $20 \mathrm{~mm}$ & $\mathrm{~V}$ & Buttering & 149.9 \\
\hline
\end{tabular}

